\title{
Chemical Traits of Fermented Alfalfa Brown Juice: Its Implications on Physiological, Biochemical, Anatomical, and Growth Parameters of Celosia
}

\author{
Nóra Bákonyi ${ }^{1}{ }^{\circledR}$, Szilvia Kisvarga ${ }^{2}$, Döme Barna ${ }^{1}$, Ibolya O. Tóth ${ }^{1}$, Hassan El-Ramady ${ }^{1,3}$, \\ Neama Abdalla ${ }^{1,4}$, Szilvia Kovács ${ }^{1}$, Margaréta Rozbach ${ }^{5}$, Csaba Fehér ${ }^{5}$, Nevien Elhawat ${ }^{1,6} \oplus$, \\ Tarek Alshaal $1,3, *$ (i) and Miklós Gábor Fári ${ }^{1}$ \\ 1 Department of Agricultural Botany, Plant Physiology and Biotechnology (MEK), Debrecen University, \\ Böszörményi Street 138, 4032 Debrecen, Hungary; nbakonyi@agr.unideb.hu (N.B.); \\ barnadoeme@gmail.com (D.B.); olahne@agr.unideb.hu (I.O.T.); ramady2000@gmail.com (H.E.-R.); \\ neama_ncr@yahoo.com (N.A.); szkovacs@agr.unideb.hu (S.K.); nevienelhawat@gmail.com (N.E.); \\ miklos0810@gmail.com (M.G.F.) \\ 2 Research Institute for Fruitgrowing and Ornamentals, National Agricultural Research and Innovation \\ Center (NARIC) Szent-Györgyi Street 4., 2100 Gödöllő, Hungary; fullerina@gmail.com \\ 3 Soil and Water Department, Faculty of Agriculture, Kafrelsheikh University, Kafr El-Sheikh 33516, Egypt \\ 4 Plant Biotechnology Department, Genetic Engineering Division, National Research Center, \\ 33-El-Behouth Street, Cairo 12622, Egypt \\ 5 Department of Applied Biotechnology and Food Science (BME-ABÉT), Szent Gellért Square 4, \\ 1111 Budapest, Hungary; rozbachgreti@gmail.com (M.R.); fehercsaba87@gmail.com (C.F.) \\ 6 Department of Biological and Environmental Sciences, Faculty of Home Economic, Al-Azhar University, \\ Sperpay Number 4 Rd, Tanta, 31732, Egypt \\ * Correspondence: alshaaltarek@gmail.com
}

Received: 3 December 2019; Accepted: 3 February 2020; Published: 7 February 2020

\begin{abstract}
Brown juice is a byproduct of fractionated green biomass during leaf protein isolation. It represents approximately $45 \%-50 \%$ of the total pressed fresh biomass. Disposal of brown juice is a serious issue in leaf protein production due to its high biological oxygen demand and carbohydrates content. The current study aimed to find a possible potential use of brown juice. Therefore, chemical and biochemical properties of brown juice-derived from alfalfa green biomass—were determined before and after fermentation by lactic acid bacteria. Additionally, the growth stimulation potential of fermented brown juice on plumed cockscomb (Celosia argantea var. plumose 'Arrabona') plants were tested. Celosia seedlings were sprayed at different rates of fermented brown juice (i.e., $0.5 \%, 1 \%$, $2.5 \%, 5 \%$, and $10 \%$ ) and tap water was applied as control. The results revealed that lactic acid bacteria successfully enhanced the stabilization of brown juice via reducing sugars content and increasing organic acids content. After fermentation, contents of glucose monomers were 15 times lower; while concentrations of lactic and acetic acids increased by 7 - and 10-fold, respectively. This caused a reduction in the $\mathrm{pH}$ of fermented brown juice by $13.9 \%$. Treating Celosia plants at lower rates of fermented brown juice (up to 1.0\%) significantly induced their growth dynamics and antioxidant capacity. Higher values of vegetative parameters were measured in treated plants compared to control. The brown juice treatments caused significant changes in histological parameters as well. The activity of catalase and peroxidase increased in plants that received fermented brown juice especially at low rates. Moreover, an increase in water-soluble protein and phenol was measured in different tissues of plants sprayed with fermented brown juice. Malondialdehyde content was lowered in treated plants compared to control. Fermented brown juice at high rates slightly reduced the amount of photosynthetic pigments; however, this reduction was not reported for low rates of fermented brown juice. These results surely illustrate the potential use of fermented alfalfa brown juice as a growth stimulator for crops particularly at rates below $2.5 \%$.
\end{abstract}


Keywords: deproteinized leaf juice; fermentation; lactic acid bacteria; plant nutrition; antioxidant capacity; ornamental plants

\section{Introduction}

Due to the continuous growth in the global population ( 7.2 billion) and malnutrition, the global demand for the protein will increase in the next years [1]. The lack of protein supply has existed as a health problem for many years and is considered as one of the main types of malnutrition in developing and developed countries [2]. Over the next decades, a dramatic increase in the global protein demand is expected and overall protein consumption is predicted to nearly double by 2050 . These rapid changes will create serious and accelerated pressure on land and water resources and their scarcity [3]. To meet the increased protein demand there are several approaches to introduce novel protein sources or alternatives $[4,5]$. The extraction of proteins from forage crops such as alfalfa, clover or grass is a potential process for the production of leaf protein concentrates (LPC), which can be utilized as feed or food but also hydrolyzed into amino acids for the cosmetics or pharma industries [6]. Alfalfa or lucerne plant is well known as the king of forage. It is a perennial flowering plant belonging to the legume family Fabaceae. This plant has several advantages including high-quality leaf protein $(50 \%-60 \%)$, strong adaptability, high nutritional value, good taste, wide distribution, and stable productivity [7]. It can also yield crude protein 2-, 3-, and 4-fold higher than peas, soybean, and wheat, respectively [8]. Therefore, alfalfa nowadays is considered as the most promising crop for LPC. Isolation of leaf protein in form of LPC aims to extract solid or insoluble proteins (i.e., the protein of mitochondria, chloroplasts, nucleoprotein, and cell wall) and soluble proteins (i.e., the soluble fraction of mitochondrial proteins, chloroplast matrix, and cytoplasm proteins). Therefore, the thermal treatment of green juice obtained by pressing the fresh biomass is needed to coagulate these types of proteins. During coagulation of leaf protein, a brown liquid byproduct is produced, and it is referred to as "brown juice". One kilogram of fresh alfalfa biomass can produce up to $500 \mathrm{~g}$ of brown juice [9]. These large amounts of brown juice are rich in protein and phenols as well as micronutrients. Plant phenolic compounds are known to be able to modulate important physiological routes like signal transduction and transcriptional regulation. Phenolic compounds in brown juice associated with auxin bioregulators [10] prove that the disposal of these amounts of valuable brown juice is a waste. Disposal is high in its costs and will waste the nutritional value of this byproduct, which would be easily adaptable to the circular economy concept; a technology that generates no further waste by utilizing all the produced renewable resources [11-13]. The main product, the leaf protein produced by coagulation, is widely studied [14]; however, the brown liquid, also known as whey or brown juice [15], has limited literature especially in the case of the plant nutrition aspect. Brown juice is mentioned in some articles as DPJ (Deproteinized Plant Juice) [16] or deproteinized leaf extracts or leaf juice, deproteinized whey [17] as a byproduct of plant protein-producing technologies. DPJ can be applied for several purposes; for instance, as a fertilizer for plants, milk for calves, excellent fodder for cattle and rabbits, medium for microbial growth, and also for in vitro rhizogenesis [18-21]. The dry matter and protein content of brown juice range from $13 \%$ to $15 \%$ and $16 \%-20 \%$, respectively, whereas the cellulose content is $25 \%-30 \%$ [18]. The alfalfa brown juice has a dry matter content of $4 \%-8 \%$ which is influenced by the species, varieties, weather conditions, phenophase, methods of harvest, and processing.

Several microorganisms like lactic acid bacteria (LAB) are useful, having advantageous features, and can be found in a range of locations from soil and natural water, to the surface of plants up to the human intestinal tract [22]. These microorganisms have been applied for decades in the fermentation processes of raw materials because of their beneficial effects. It has been validated that ferments containing lactic acid bacteria (or other PGPB-plant growth-promoting bacteria) (isolated from different sources) have plant growth-promoting properties [23]. Lactic acid bacteria containing ferments were proven to be effective biofertilizers, biocontrol agents, and biostimulants because they 
promote plant health, growth, and resilience as they improve nutrient availability [24], however, the functional roles of these bacteria in the phytomicrobiome have not been discovered yet [25]. Celosia genus is native to tropical America and Africa. Celosia argentea is a food crop in West Africa as well as a medicinal plant in China and India with considerable pharmacological properties [26]. Among 13 green leafy vegetables, Celosia argentea was one of the few that had exceptionally high iron $\left(13.5 \mathrm{mg} 100 \mathrm{~g}^{-1}\right)$, calcium (188 mg $\left.100 \mathrm{~g}^{-1}\right)$, sodium $\left(240.6 \mathrm{mg} 100 \mathrm{~g}^{-1}\right)$, ascorbic acid $\left(26 \mathrm{mg} 100 \mathrm{~g}^{-1}\right)$, and $\beta$-carotene


weight which was one of the highest, while its moisture and protein content was found to be 87.6 and


characterized by a wide range in size and color of flowers. Plumosa cultivars can grow from dwarf to tall. The inflorescence of narrow pyramidal, plume-like, is consistent with tiny, vivaciously colored (e.g., orange, red, purple, yellow) flowers.

This research aimed to enhance the stability of stored brown juice through fermentation by lactic acid bacteria; assess physiochemical traits of alfalfa brown juice before and after fermentation; determine whether the different fermented brown juice concentrations have any impact on the formation of the stem's anatomy; and evaluate the potential of fermented brown juice as a growth stimulator using Celosia argantea var. plumosa as a model plant.

\section{Materials and Methods}

\subsection{Brown Juice Production and Its Characteristics}

\subsubsection{Source of Alfalfa Biomass}

A field experiment of alfalfa (Medicago sativa L. var. Hunor-40) was carried out during 2017 and 2018, under the GINOP (2.2.1-15-2017-00051) project labeled Proteomill [28], at the experimental farm of Tedej Zrt., Hajdúnánás, Hungary. The seeds were sown on chernozem soil at the rate of $25 \mathrm{~kg} \mathrm{ha}^{-1}$. All recommended agronomic practices such as irrigation, weed control, and fertilization were done. The alfalfa fresh biomass was used as a source for brown juice. The first cut of alfalfa plants was carried out in the middle of May 2018 directly before the flowering stage since at this time protein in alfalfa biomass is at its highest content. Plants were harvested early morning and directly transferred in special boxes to the laboratory to avoid the degradation of protein by protease enzyme.

\subsubsection{Extraction of Brown Juice}

Alfalfa fresh biomass was fractionated into the fiber, leaf protein concentrate (LPC), and deproteinized plant juice (DPJ, brown juice) as follows: fresh biomass was pressed and pulped mechanically using Angel Juicer (5500, Angel Ltd., Praha, Czech Republic) into fiber and green juice fractions. Later, the green juice was thermally treated at $80{ }^{\circ} \mathrm{C}$ in order to coagulate mainly the chloroplastic and cytoplasmic proteins. After thermal coagulation, the mixture was left at room temperature for approximately $10 \mathrm{~min}$, then the coagulant was separated from brown juice using moistened $100 \%$ natural unbleached cotton cloth filter (pore size $=10$ microns).

\subsubsection{Fermentation of Brown Juice}

Fermentation of brown juice was necessary to increase the stability of brown juice and its storage period because fresh brown juice rapidly spoils due to high sugar and protein content. After cooling, the brown juice was transferred into a 20-L container and inoculated with AdiSil LG-100 Perfect (Fides Agro, Šardice, Czech Republic) containing heterofermentative lactic acid bacterial cultures $\left(10^{11} \mathrm{CFU}\right.$ $\mathrm{g}^{-1}$, Pediococcus acidilactici, Lactobacillus paracasei, Lactobacillus plantarum) at the rate of $0.01 \mathrm{~g} \mathrm{~L}^{-1}$. The inoculated samples were kept at $35^{\circ} \mathrm{C}$ for $48 \mathrm{~h}$. 


\subsubsection{Determination of Lactic Acid Bacteria}

The qualitative measurement of lactic acid bacteria in the fermented brown juice was determined at the end of the fermentation process by methylene blue test [29]. Briefly, $1 \mathrm{~mL}$ methylene blue reagent was added to $10 \mathrm{~mL}$ fermented brown juice, and then the samples were incubated at $37^{\circ} \mathrm{C}$ for $48 \mathrm{~h}$. The time needed for the disappearing of blue color is an indication of lactic acid bacteria density in the solution.

\subsubsection{Chemical Properties of Brown Juice}

The $\mathrm{pH}$ of brown juice was measured by pH-meter (Mettler Toledo S20 Seven Easy, Switzerland). Electrical conductivity (EC) was determined using EC-meter (Thermo Scientific, Orion Model 209A ${ }^{+}$ type, Germany). Degree Brix was recorded manually by a refractometer (RBR32-ATC, Germany). The content of macro- and micro-elements in brown juice before and after fermentation was measured using $\mathrm{HNO}_{3}-\mathrm{H}_{2} \mathrm{O}_{2}$ wet digestion method as described by Kovács et al. [30]. Briefly, $1 \mathrm{~g}$ lyophilized brown juice was weighed into a Kjeldahl digestion tube, then $10 \mathrm{~mL} \mathrm{HNO}_{3}(99 \%$, VWR International, USA) was added. The mixture was placed on the heater at $100{ }^{\circ} \mathrm{C}$ for $45 \mathrm{~min}$; after cooling $5 \mathrm{~mL} \mathrm{H}_{2} \mathrm{O}_{2}$ (30\%, Sigma-Aldrich, St. Louis, MO, USA) was added for complete oxidation of organic materials and samples were kept on the heater for additional $45 \mathrm{~min}$ at $120^{\circ} \mathrm{C}$. After cooling the sample volume was brought to $50 \mathrm{~mL}$ using distilled water and then filtered using MN $640 \mathrm{~W}$ filter paper. The elemental content of brown juice was measured by ICP-OES spectrometer (Perkin Elmer made OPTIMA 3300 DV, Pittsboro, NC, USA).

Total phenol content in brown juice was determined spectrophotometerically using Ultrospec spectrophotometer (2100 pro, Amersham BioSciences, Amersham, United Kingdom) as previously described by Boór and Bélafiné Bakó [31]. Determination of total N content was carried out by Kjeldahl method [32] (Sparks et al., 1996). Concentrations of glucose and organic acids were determined by HPLC using BioRad (Hercules, CA, USA) Aminex HPX-87H $(300 \times 7.8 \mathrm{~mm})$ column at $65^{\circ} \mathrm{C}$, and a refractive index detector. The eluent was $5 \mathrm{mmol} \mathrm{L}^{-1} \mathrm{H}_{2} \mathrm{SO}_{4}$ at a flow rate of $0.5 \mathrm{~mL} \mathrm{~min}^{-1}$. The injection volume was $40 \mu \mathrm{L}$. Concentrations of fructose, xylose, and arabinose were determined by HPLC using Phenomenex (Torrance, CA, USA) Rezex RPM-Monosaccharide $\mathrm{Pb}^{+2}(300 \times 7.8 \mathrm{~mm})$ column at $80^{\circ} \mathrm{C}$, and a refractive index detector. The eluent was ultrapure (milli-Q) water at a flow rate of $0.5 \mathrm{~mL} \mathrm{~min}^{-1}$. The injection volume was $40 \mu \mathrm{L}$. Total sugars include monomer sugars and sugar oligomers solubilized. Monomer sugar concentrations were determined by HPLC after a sample preparation of $5 \mathrm{~min}$ boiling followed by centrifugation $(5000 \mathrm{rpm})$ to eliminate residual proteins. To determine the oligomer sugar content of the samples, weak acid hydrolysis was performed. The samples were mixed with $8 \mathrm{w} / \mathrm{w} \% \mathrm{H}_{2} \mathrm{SO}_{4}$ at a volume ratio of $1: 1$ and treated at $120^{\circ} \mathrm{C}$ in the autoclave for $15 \mathrm{~min}$ to decompose sugar oligomers into monomers, which were determined by HPLC.

\subsection{Celosia Experiment}

This experiment was carried out to assess the potential use of brown juice as a plant growth stimulator. In the present study, Celosia (Celosia argantea var. plumosa 'Arrabona') was used as a model plant for examining physiological, biochemical, and anatomical responses to fermented brown juice in our department and the National Agricultural Research and Innovation Center (NARIC, Budapest, Hungary). Celosia seeds were obtained from NARIC.

\subsubsection{Experimental Design}

A greenhouse pot experiment was carried out at the NARIC. The experimental layout was the Randomized Complete Block design (RCB) with 15 replicates. A polyethylene pot $(7 \times 7 \times 8 \mathrm{~cm})$ was filled with potting soil for horticultural crops (Klassman-Deilmann TS 3 FINE type, Geeste, Germany). The physical and chemical properties of potting soil are structure fine, $\mathrm{pH}\left(\mathrm{H}_{2} \mathrm{O}\right) 6, \mathrm{~N} 140 \mathrm{mg} \mathrm{L}^{-1}$,




sown in nursery substrate on 16th July 2018 and 4 days later germinated seeds were fertilized using different rates of brown juice. After two weeks, identical and healthy seedlings were transferred to the pots. Fermented brown juice was applied as a foliar application at rates of $0.5 \%, 1.0 \%, 2.5 \%, 5 \%$, and $10 \%$. The final application volume was $250 \mathrm{~mL}$ and equally shared among all replicates of the same treatment. The control plants were sprayed with tap water. Brown juice was applied once a week from starting the experiment on 16th July until 14th August, then we applied brown juice twice a week (Tuesdays and Fridays) until the end of the experiment on 11th September. At the end of the experiment, the following vegetative parameters were measured: root and stem length, root and stem volume, root and stem fresh and dry mass, and the number of leaves.

\subsubsection{Determination of Water-Soluble Protein and Antioxidant Enzymes}

Water-soluble protein fraction of lyophilized root, stem, and leaf tissues was determined using Coomassie Brilliant Blue G-250 according to Bradford [33] in triplicate with bovine serum albumin as standard. Briefly, $20 \mathrm{mg}$ plant tissue was ground into homogenate in the mortar with quartz sand, then transferred into a volumetric flask, and then suspended in $100 \mathrm{~mL}$ distilled water to extract water-soluble protein fraction. The solution was centrifuged at $3000 \mathrm{rpm}$ for $5 \mathrm{~min}$. The supernatant was used for the assay of water-soluble protein content using UV-160A spectrophotometer (Shimadzu, Japan) at $595 \mathrm{~nm}$. Peroxidase activity was determined in lyophilized roots, stems, and leaves of Celosia plants according to Roxas et al. [34]. Briefly, $100 \mathrm{mg}$ plant tissue was macerated in $4 \mathrm{~mL}$ of phosphate buffer $0.01 \mathrm{M}$ ( $\mathrm{pH}$ 6.0). The homogenate was centrifuged at 13,000 rpm for $10 \mathrm{~min}$ to collect the supernatant. The supernatant was used to measure peroxidase activity using UV-160A spectrophotometer (Shimadzu, Japan) at $460 \mathrm{~nm}$ for $1 \mathrm{~min}$. The unit of peroxidase activity was defined with the increase of one unit of absorbance per $\mathrm{mL}^{-1} \mathrm{~min}^{-1} \mathrm{~g}^{-1}$ of dry matter. Catalase (CAT) activity in lyophilized Celosia leaves was measured by following the decomposition of hydrogen peroxide at $240 \mathrm{~nm}$ according to Woodbury et al. [35]. The reaction included $0.2 \mathrm{~mL}$ supernatant, $1.5 \mathrm{~mL}$ phosphate buffer ( $\mathrm{pH} 7.8,0.2 \mathrm{M}$ ), and $1 \mathrm{~mL}$ distilled water. The colorimetric determination of CAT was conducted by the model UV-160A spectrophotometer (Shimadzu, Japan) at $240 \mathrm{~nm}$. The biochemical reaction was initiated by adding $0.3 \mathrm{~mL} 0.1 \mathrm{M} \mathrm{H}_{2} \mathrm{O}_{2}$. The activity of CAT was expressed as $\mu \mathrm{mol} \mathrm{H}_{2} \mathrm{O}_{2}$ consumed/mg protein/min.

\subsubsection{Malondialdehyde Measurement}

The malondialdehyde (MDA) content was determined from roots, stems, and leaves of Celosia plants by the method of Zhang and Huang [36]. Briefly, $100 \mathrm{mg}$ lyophilized sample was homogenized in $1 \mathrm{~mL} 0.1 \%(w / v)$ TCA solution using cold mortar and pestle. The homogenates were centrifuged at $10,000 \times \mathrm{g}$ for $10 \mathrm{~min}$. Then, $4 \mathrm{~mL}$ of $0.5 \%$ thiobarbituric acid (TBA) in $20 \%$ TCA solution was added into $1 \mathrm{~mL}$ of supernatant and incubated at $96^{\circ} \mathrm{C}$ for $30 \mathrm{~min}$. The tubes were cooled by transferring into an ice bath. The absorbance of the supernatant was recorded at $532 \mathrm{~nm}$. The standard curve was generated from MDA standard. The concentration of MDA of samples was calculated from the absorbance knowing calibration curve.

\subsubsection{Photosynthetic Pigment}

The photosynthetic pigment content of Celosia leaves was measured spectrophotomertically based on methods described by Porra et al. [37]. For the sample preparation, the leaf disc was cut and the chlorophyll content was extracted by $\mathrm{N}^{\prime} \mathrm{N}$ dimethyl-formamide overnight. The absorbance was measured by spectrophotometer (Amersham Biosciences Ultrospec 2100 Pro UV/Visible) on 663 and $645 \mathrm{~nm}$ wavelengths and from these data, the $\mathrm{chl} a, b, a+b$, and $\mathrm{a} / \mathrm{b}$ ratio were calculated.

\subsubsection{Histology}

We used three specimens per treatment for the stem's histological examination. Each plant was cut into smaller pieces and the third internodes (from beneath) fixed separately in a mixture of 
glycerin:alcohol:water (1:1:1) for a week. Then, several cross-sections were prepared using blades, after clarification, they were stained with Toluidin-blue. All analyses were performed under a light microscope (Zeiss Axioscope 2+; Zeiss International, Oberkochen, Ostalbkreis, Germany) with a compatible camera, and the Scope Photo software (Scopetek, München, Germany) was used for processing the images. For the measurement, we used at least 15 different cross-sections per internodes. The measured parameters were thick at the epidermis, primary cortex, pith, primary and secondary vascular tissue.

\subsection{Statistical Analysis}

Before the ANOVA test, Levene's Test for Equality of Variances was performed. The Levene's test for different variables at the six treatments of brown juice (i.e., $0 \%, 0.5 \%, 1 \%, 2.5 \%, 5 \%$, and $10 \%$ ) was negative, $p<0.05$, and then the variances showed homogeneity. Results of the experiments were subjected to one-way (for fresh and dry weight, chlorophyll pigments, protein, MDA, POD, and catalase) and two-way (for root and shoot lengths, root and shoot volumes, and number of leaves) ANOVA by 'SigmaPlot 12.0' software and the means were compared by Duncan's Multiple Range Test [38] at $p<0.05$.

\section{Results}

\subsection{Characteristics of Brown Juice}

\subsubsection{Chemical Traits of Brown Juice}

The fermentation of brown juice significantly changed its chemical properties (Table 1). Inoculation of fresh brown juice by lactic acid bacteria under anaerobic conditions caused a $13.9 \%$ reduction in $\mathrm{pH}$. The degree Brix slightly increased after fermentation as it changed from 7.03 to 7.20 . Total phenolic content dropped down after fermentation by almost $33.4 \%$. Moreover, EC of fermented brown juice was $25.2 \%$ lower than fresh brown juice. Additionally, the density of brown color, that brown juice has, was reduced as its absorbance at $430 \mathrm{~nm}$ was diminished by $35.9 \%$.

Table 1. Physiochemical characteristics of alfalfa brown juice before and after fermentation using lactobacillus.

\begin{tabular}{|c|c|c|}
\hline Parameter & Before & After \\
\hline $\mathrm{pH}$ & $4.54 \pm 0.03$ & $3.91 \pm 0.05$ \\
\hline $\mathrm{Brix}^{+}(\%)$ & $7.03 \pm 0.02$ & $7.20 \pm 0.01$ \\
\hline Total phenolic content $\left(\mu \mathrm{g} \mathrm{mL}^{-1}\right)$ & $36.5 \pm 1.19$ & $24.26 \pm 0.55$ \\
\hline Electrical conductivity $\left(\mathrm{dS} \mathrm{m}^{-1}\right)$ & $11.13 \pm 0.11$ & $8.47 \pm 0.06$ \\
\hline Color-absorbance (at $430 \mathrm{~nm}$ ) & $0.594 \pm 0.006$ & $0.381 \pm 0.004$ \\
\hline Lactic acid bacteria $\left(\mathrm{CFU} \times 10^{8}\right.$ per $\left.\mathrm{mL}\right)$ & $11.33 \pm 4.04$ & $8.00 \pm 4.36$ \\
\hline \multicolumn{3}{|l|}{ Sugars content $\left(g^{-1}\right)$} \\
\hline Glucose monomer $H$ & $21.19 \pm 0.64$ & $1.33 \pm 0.03$ \\
\hline Glucose oligomer $H$ & $2.80 \pm 0.58$ & $\mathrm{Nd} \ddagger$ \\
\hline Xylose monomer $\mathrm{Pb}$ & $12.0 \pm 0.06$ & nd \\
\hline Xylose oligomer $\mathrm{Pb}$ & $1.90 \pm 0.03$ & $0.60 \pm 0.02$ \\
\hline Arabinose monomer $\mathrm{Pb}$ & nd & $0.10 \pm 0.01$ \\
\hline Arabinose oligomer $\mathrm{Pb}$ & $1.50 \pm 1.16$ & $0.64 \pm 0.01$ \\
\hline Fructose monomer $\mathrm{Pb}$ & $3.70 \pm 0.02$ & $0.89 \pm 0.01$ \\
\hline Fructose oligomer $\mathrm{Pb}$ & nd & nd \\
\hline \multicolumn{3}{|l|}{ Acids content $\left(g L^{-1}\right)$} \\
\hline Acetic acid $H$ & $1.5 \pm 0.02$ & $10.4 \pm 0.03$ \\
\hline Lactic acid $H$ & $5.0 \pm 0.25$ & $50.1 \pm 0.68$ \\
\hline Propionic acid $H$ & nd & $1.2 \pm 0.02$ \\
\hline
\end{tabular}

Notes: ${ }^{\dagger}$ Degree Brix $=$ water-soluble sugar content (one degree Brix means $1 \mathrm{~g}$ of sucrose in $100 \mathrm{~mL}$ aqueous solution); ${ }^{\ddagger}$ nd = not detected; sample size $(n=6) ; H$-samples run on Aminex HPX $87 \mathrm{H}$ column; $P b$-samples run on Aminex HPX $87 \mathrm{~Pb}$ column. 


\subsubsection{Contents of Sugars and Organic Acids in the Brown Juice}

Furthermore, the effect of lactic acid bacteria was not only reflected in the chemical characteristics of brown juice but also was noticed in sugars content. Interestingly, contents of monomer and oligomer forms of glucose, xylose, arabinose, and fructose reduced after fermentation, except arabinose monomer which was below the detected limit in fresh brown juice and became $0.1 \mathrm{~g} \mathrm{~L}^{-1}$ after fermentation; also, no fructose oligomer was detected either in fresh or fermented brown juice samples (Table 1). The highest decrease was found for glucose monomer as it lowered by 16 times in fermented brown juice compared to fresh brown juice. Fructose monomer, also, was four times lower in fermented brown juice, while arabinose oligomer recorded a decrease of $57.3 \%$ (Table 1 ). In contrast to sugars content, organic acids such as acetic, lactic, and propionic acids were considerably increased after fermentation by lactic acid bacteria. The content of lactic acid was 10 -fold higher in fermented brown juice, as the highest recorded increase for any measured organic acid, while acetic acid content changed by seven times higher. Propionic acid content was below the detected limit in fresh brown juice; however, after fermentation it increased, recording $1.2 \mathrm{~g} \mathrm{~L}^{-1}$ (Table 1).

\subsubsection{Macro- and Microelements Content of Brown Juice}

Content of macro-and microelements of brown juice meaningfully changed due to fermentation by lactic acid bacteria (Table 2). Fermentation of brown juice resulted in a substantial reduction in the concentration of $\mathrm{N}, \mathrm{P}, \mathrm{K}$, and $\mathrm{S}$ by $11 \%, 32 \%, 38 \%$, and $21 \%$, respectively. Otherwise, the contents of other elements displayed in Table 2 were found to be considerably higher after treating brown juice with lactic acid bacteria under anaerobic conditions. Interestingly, concentrations of $\mathrm{Ca}, \mathrm{Mg}, \mathrm{Mo}, \mathrm{Sr}$, and Ba were increased by 55\%,63\%, 36\%, 54\%, and 109\%, respectively. Furthermore, Na, Mn, Fe, Zn, B, and $\mathrm{Al}$ contents were 14.5-, 2.0-, 11.0-, 2.5-, 1.5-, and 5.7-fold higher, respectively, in fermented brown juice than fresh brown juice. No $\mathrm{Cu}$ was detected in brown juice either fresh or fermented.

Table 2. Content of macro- and microelements $\left(\mathrm{mg} \mathrm{L}^{-1}\right)$ in alfalfa brown juice before and after fermentation.

\begin{tabular}{ccc}
\hline Elements & Before & After \\
\hline $\mathbf{N}$ & $18.24 \pm 0.66^{\dagger}$ & $16.19 \pm 0.01$ \\
$\mathbf{P}$ & $286 \pm 30$ & $238 \pm 5.98$ \\
$\mathbf{K}$ & $6090 \pm 571$ & $5276 \pm 153$ \\
$\mathbf{C a}$ & $1270 \pm 70$ & $2326 \pm 66.58$ \\
$\mathbf{M g}$ & $379 \pm 16$ & $739 \pm 24.83$ \\
$\mathbf{N a}$ & $31.03 \pm 8.70$ & $452 \pm 15.02$ \\
$\mathbf{S}$ & $352 \pm 22$ & $425 \pm 6.57$ \\
$\mathbf{M n}$ & $1.61 \pm 0.13$ & $4.66 \pm 0.09$ \\
$\mathbf{M o}$ & $0.29 \pm 0.12$ & $0.45 \pm 0.01$ \\
$\mathbf{F e}$ & $2.04 \pm 0.45$ & $32.20 \pm 0.86$ \\
$\mathbf{C u}$ & $0.06 \pm 0.05$ & $\mathrm{nd}$ \\
$\mathbf{Z n}$ & $2.03 \pm 0.19$ & $8.59 \pm 0.21$ \\
$\mathbf{S r}$ & $5.46 \pm 0.24$ & $8.80 \pm 0.23$ \\
$\mathbf{B}$ & $3.69 \pm 0.33$ & $11.61 \pm 0.33$ \\
$\mathbf{A l}$ & $0.24 \pm 0.27$ & $1.67 \pm 0.13$ \\
$\mathbf{B a}$ & $0.39 \pm 0.02$ & $0.94 \pm 0.02$ \\
\hline
\end{tabular}

Notes: ${ }^{\dagger}$ Standard deviation; ${ }^{\ddagger}$ not detected; sample size $(n=6)$.

\subsection{Fermented Brown Juice as A Growth Stimulator}

The possible utilization of fermented brown juice as a growth stimulator was evaluated. Celosia seedlings were treated with different doses of fermented brown juice through foliar application. 


\subsubsection{Growth Dynamic of Celosia}

Spraying of Celosia seedlings with fermented brown juice significantly induced the development of stems (Figure 1). The application of brown juice at low concentrations had better effects on plant growth than higher concentrations. Spraying Celosia plants with $0.5 \%$ of fermented brown juice resulted in the tallest stem $(26.0 \mathrm{~cm})$; however, higher concentrations drastically diminished stem length. For instance, at the rate of $10 \%$ fermented brown juice stem length was $15.6 \mathrm{~cm}$ (Figure 1A). The root system of Celosia plants responded to fermented brown juice differently to the shoot part. All rates of brown juice resulted in very similar lengths of root systems except the rate of $10 \%$ which caused a significant reduction in root systems $(16.9 \mathrm{~cm})$. However, the tallest root system was found in control plants sprayed with tap water (Figure 1A).

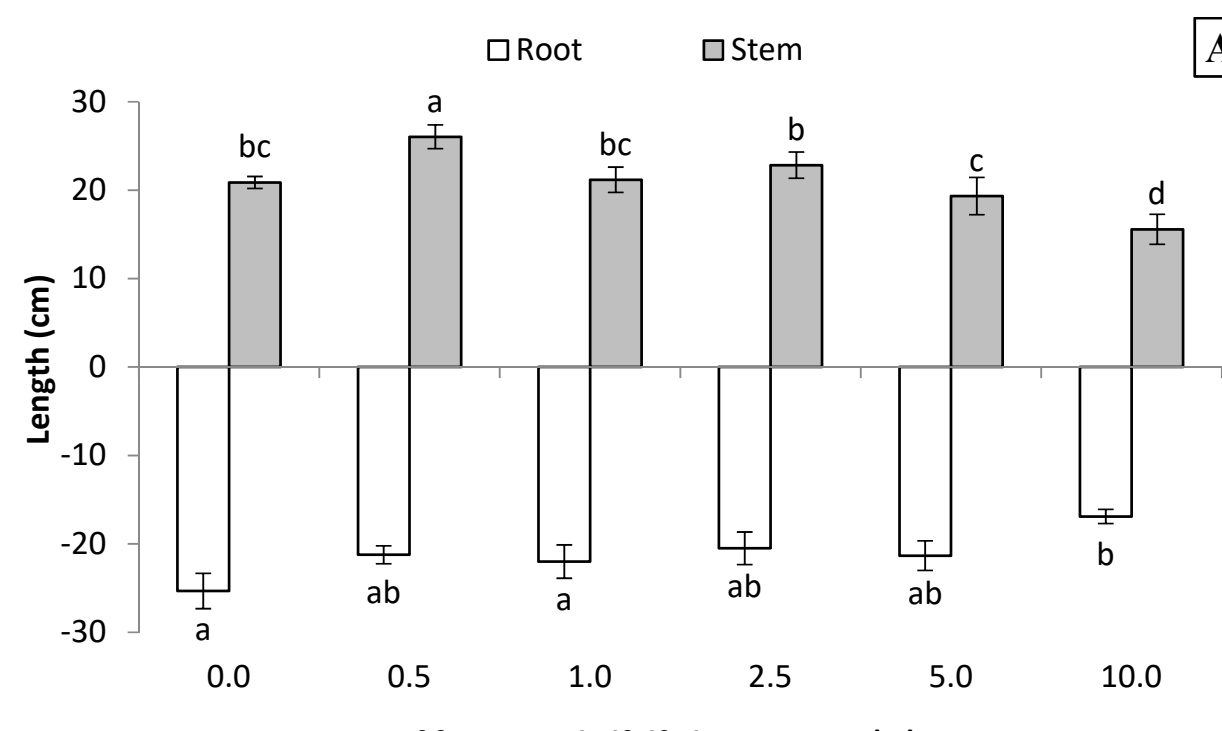

Rates of fermented alfalfa brown juice (\%)

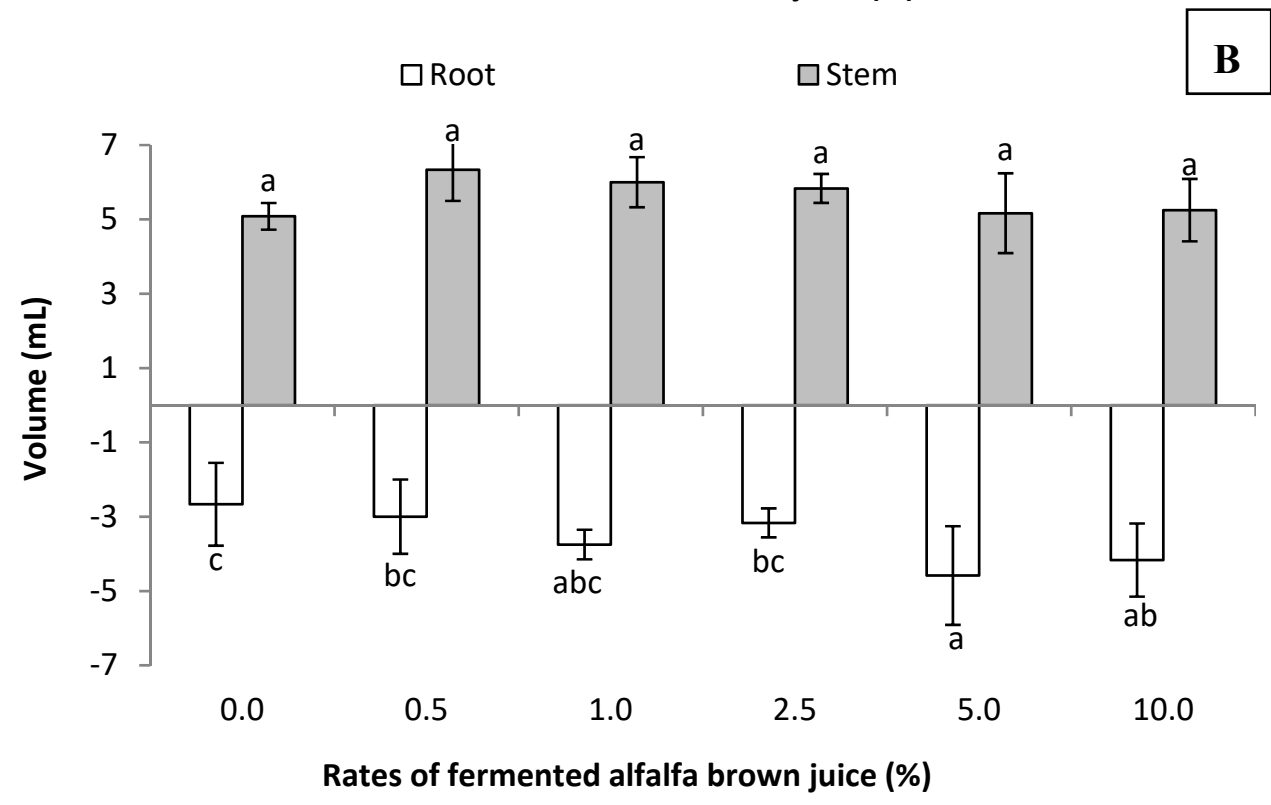

Figure 1. Length (A) and volume (B) of root and stem systems of Celosia plants fertilized at different rates of fermented alfalfa brown juice applied as a foliar application. Sample size $(n=6)$. Different letters above the same columns show significant differences at the level of $p<0.05$.

Although, length of shoot and root systems is considered as a good indicator for plant growth and its response to the newly added fertilizers and/or stimulators, alone it does not precisely describe 
the real status of plant health. Therefore, to have a comprehensive description of the shoot and root systems, their volumes should be also measured. This is very essential particularly to describe the root system and its architecture as shoot parts respond to growth conditions in a proportional way. Concerning stem volume, similar findings as for its length were reported. At lower rate of fermented brown juice $(0.5 \%)$ the highest volume of stem $\left(6.0 \mathrm{~cm}^{3}\right)$ was measured while increasing the rate of fermented brown juice gradually and significantly declined the stem volume and lowest volume $\left(2.3 \mathrm{~cm}^{3}\right)$ was measured for plants sprayed at $10 \%$ fermented brown juice (Figure 1B). Results of root volume presented in Figure 1B displayed that although control plants had the tallest root length, its volume was the lowest among all the treatments. This means that control plants had long roots but unbranched ones with few lateral roots. All treated Celosia plants with fermented brown juice showed higher root volume compared to control plants. The highest root volume was noticed at plants sprayed with $5 \%$ of fermented brown juice. Additionally, results show that higher rates of fermented brown juice, i.e., $5 \%$ and $10 \%$ resulted in higher measured root volumes (Figure 1B).

Fresh mass of different Celosia tissues (roots, stems, and leaves) significantly responded to spraying the plants with different rates of fermented brown juice as shown in Figure 2. Fresh mass of roots, stems, and leaves of all plant parts was higher for plants treated with fermented brown juice compared to control plants sprayed with tap water. The highest fresh mass of roots, stems, and leaves was $4.30,8.87$, and $8.49 \mathrm{~g} \mathrm{plant}^{-1}$, respectively, that measured at rates of $2.5 \%, 0.5 \%$, and $5 \%$ fermented brown juice, respectively (Figure 2A). Control plants displayed the lowest dry mass of roots, stems, and the number of leaves $0.17,0.31$, and $0.55 \mathrm{~g} \mathrm{plant}^{-1}$, respectively; while sprayed plants with $2.5 \%$ fermented brown juice showed the highest determined dry mass $0.44,0.64$, and $0.86 \mathrm{~g} \mathrm{plant}^{-1}$, for roots, stems, and leaves, respectively (Figure 2B). All rates of fermented brown juice, except $10 \%$, significantly increased the number of leaves per plant (Figure 2C). Applying fermented brown juice at the rate of $10 \%$ significantly decreased the number of leaves not only compared to other fermented brown juice rates but also control plants. The highest number of leaves per plant was 18 and was counted for plants treated with $1 \%$ fermented brown juice. However, the differences between treatments of $0.5 \%$, $1 \%, 2.5 \%$, and $5 \%$ of fermented brown juice were not significant.

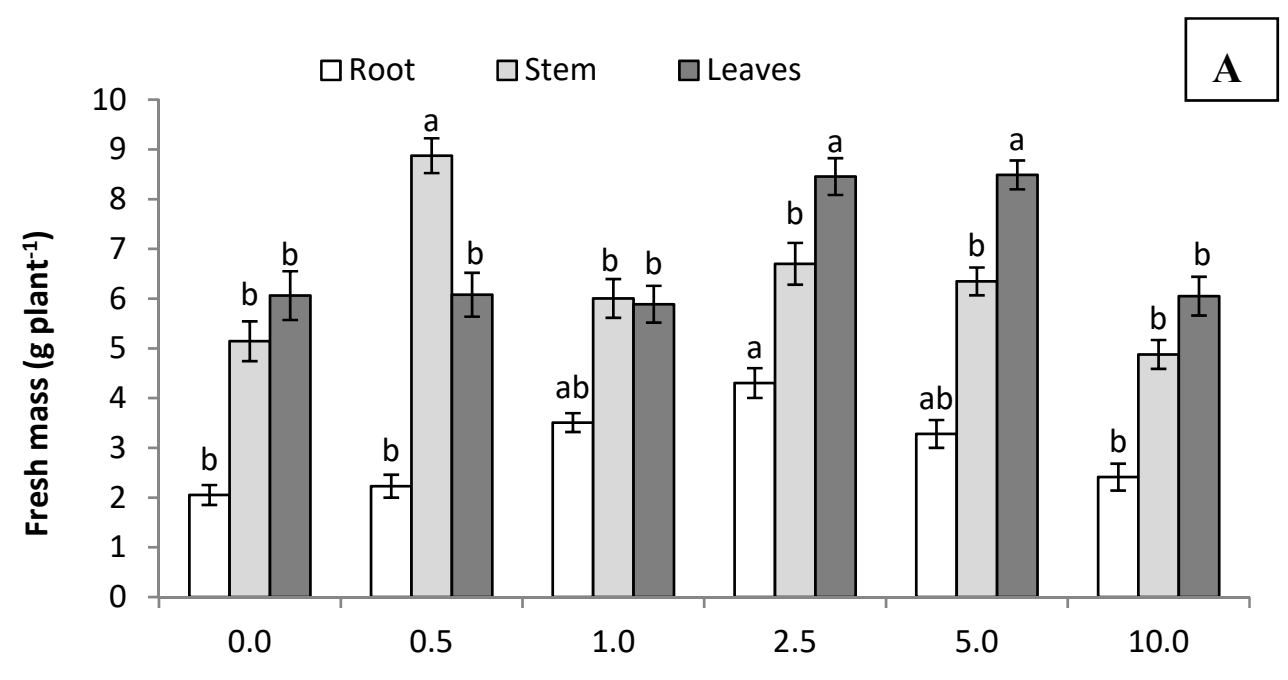

Figure 2. Cont. 

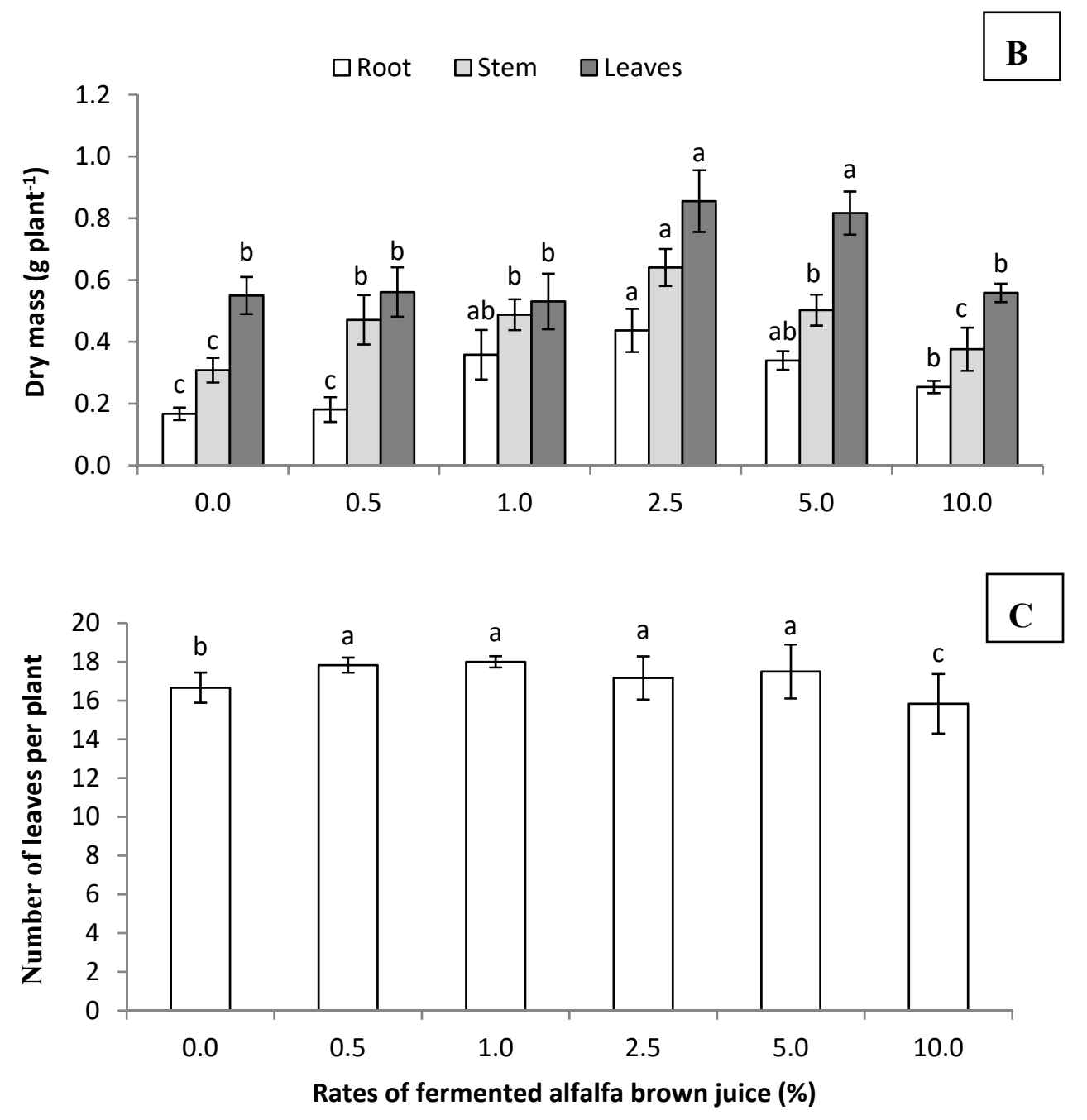

Figure 2. Fresh (A) and dry (B) masses and the number of leaves (C) of different plant tissues (roots, stems, and leaves) of Celosia plants sprayed at different rates of fermented alfalfa brown juice. Sample size $(n=6)$. Different letters above the same columns show significant differences at the level of $p<0.05$.

\subsubsection{Antioxidant Capacity of Celosia Plants Treated with Fermented Brown Juice}

Spraying Celosia plants with fermented brown juice significantly induced the activity of catalase (CAT) enzyme in the leaves (Figure 3A). All treated plants had higher activities of CAT enzyme compared to control plants (sprayed with tap water). However, increasing the rate of applied brown juice gradually reduced the CAT activity up to $5 \%$, but this reduction was still higher than the control. Treated Celosia plants at the rate of $10 \%$ achieved the highest CAT activity among all treatments $\left(0.290 \mu \mathrm{moL} \mathrm{H}_{2} \mathrm{O}_{2}\right.$ consumed $\mathrm{mg}^{-1}$ protein $\left.\mathrm{min}^{-1}\right)$.

Different Celosia plant tissues (i.e., root, stem, and leaf) showed a significant response of peroxidase enzyme activity (POD) to added fermented brown juice (Figure 3B). Higher rates of fermented brown juice above $1.0 \%$ resulted in higher POD activity in the root system than both lower rates and control plants. The root POD activity in treatments of $2.5 \%, 5 \%$, and $10 \%$ of fermented brown juice was higher than lower rates and the control; however, no statistically significant differences were calculated among these treatments. Interestingly, applying fermented brown juice at the rate of $1 \%$ resulted in the lowest determined activity of POD in the root system among all treatments including the control plants. The activity of POD in the stem tissue of Celosia plants was totally in contrast to POD activity in the root system (Figure 3B). The high rates of fermented brown juice above $1 \%$ showed lower POD activity in the stem than low rates (i.e., $0.5 \%$ and $1 \%$ ) and control plants. The lowest POD activity in stems 
was noticed when plants were sprayed at $10 \%$ fermented brown juice, while the highest measured POD activity in the stem was found for plants that received $0.5 \%$ fermented brown juice (Figure 3B). Except for treatments of $2.5 \%$ and $5 \%$ fermented brown juice, all other treatments including control plants showed similar POD activity in leaf tissue without significant differences. The highest leaf POD activity was measured in the leaves of treated plants with $2.5 \%$ fermented brown juice, while at the rate of 5\% fermented brown juice the lowest leaf POD activity was determined (Figure 3B).

Malondialdehyde (MDA) content in different tissues of Celosia plants was measured as a marker for the degree of lipid peroxidation of unsaturated fatty acids due to oxidative stress. In the root system of Celosia plants, the highest measured value of MDA content was denoted in control plants. All treated plants with fermented brown juice had lower root MDA content than control plants. However, the response of treated plants with fermented brown juice hesitated as no clear trend was seen. The lowest applied rate $1 \%$ fermented brown juice showed the lowest root MDA content, while the highest root MDA content was measured in the root system of plants sprayed with $2.5 \%$ fermented brown juice (Figure 3C). In contrast to the root system, stem MDA content was found to increase as the rate of fermented brown juice increased up to $5 \%$ then reduced at the rate $10 \%$ recording the lowest MDA content in stem tissue among all treated plants with fermented brown juice. However, the lowest MDA content in the stem was displayed in control plants. Leaves of control plants showed higher MDA content than plants that received different rates of fermented brown juice. No significant differences were found in the MDA content of leaves of plants sprayed at the rates of $1 \%, 2.5 \%$, and $5 \%$ fermented brown juice (Figure 3C). However, the lowest leaf MDA content was determined in the leaves of plants treated with $0.5 \%$ fermented brown juice.



Figure 3. Cont. 




Figure 3. The activity of catalase (A) and peroxidase (B) and malondialdehyde content (C) in different plant tissues (roots, stems, and leaves) of Celosia plants sprayed at different rates of fermented alfalfa brown juice. Sample size $(n=6)$. Different letters above the same columns show significant differences at the level of $p<0.05$.

\subsubsection{Phenolic, Protein, and Photosynthetic Pigments Contents}

The results of water-soluble phenol content are depicted in Figure 4A. Different plant tissues of Celosia plants possessed different water-soluble phenol contents as the root system showed the lowest content, while the highest water-soluble phenol content was measured in leaves. The addition of fermented brown juice as a foliar application to Celosia plants significantly affected the water-soluble phenol content in the root system. The highest water-soluble phenol content $\left(46.7 \mu \mathrm{g} \mathrm{g}^{-1}\right)$ was measured in the root system of plants that received $0.5 \%$ fermented brown juice, while, when plants were allowed to grow in the presence of $10 \%$ fermented brown juice, the water-soluble phenol content was $12.8 \mu^{-1} g^{-1}$ (Figure 4A). The root system of the control plant displayed $18.6 \mu \mathrm{g} \mathrm{g}^{-1}$ water-soluble phenol content. In stem tissues, water-soluble phenol content in plants treated with fermented brown juice showed lower water-soluble phenol content than control plants. Increasing the rate of fermented brown juice up to $2.5 \%$ gradually increased the content of water-soluble phenol in stem tissues, then a linear increase was recorded when rates of fermented brown juice were increased up to $10 \%$. The highest stem water-soluble phenol content $\left(56.8 \mu \mathrm{g} \mathrm{g}^{-1}\right)$ was measured for control plants (Figure $4 \mathrm{~A}$ ). Except for treatment of $0.5 \%$ fermented brown juice, all fermented brown juice rates showed higher water-soluble phenol content in leaf tissues. The highest water-soluble phenol content $\left(\mu \mathrm{g} \mathrm{g}^{-1}\right)$ was measured in leaves of plants that received 1\% fermented brown juice; then a gradual decrease was noticed with increasing the rate of fermented brown juice up to $10 \%$ (Figure $4 \mathrm{~A}$ ).

The content of water-soluble protein was higher in leaf tissue followed by the root system, while the lowest content was denoted in stem tissue. Significantly, the application of fermented brown juice improved water-soluble protein content in the root system. Treatments of $1 \%, 2.5 \%$, and $10 \%$ fermented brown juice displayed higher water-soluble protein content than control and treatments of $0.5 \%$ and $5 \%$ (Figure 4B). The lowest water-soluble protein content $\left(2.18 \mathrm{mg} \mathrm{g}^{-1}\right)$ was measured in the root system of plants treated with $0.5 \%$ of fermented brown juice. Similar results were found in stem tissue of Celosia plants, where all treated plants with fermented brown juice had higher water-soluble protein content than control except treatment of $0.5 \%$ fermented brown juice. Although the content of water-soluble protein in leaves was higher than measured in the root system, the trend in which roots and leaves responded to spraying with fermented brown juice was almost the same. Leaf water-soluble protein contents in plants of treatments of $0.5 \%$ and $5 \%$ were the lowest among all treatments including the control. Other fermented brown juice rates enhanced the water-soluble protein content in leaf tissue over the control plants (Figure 4B). 
Significant differences were noticed in a few cases among treatments for chlorophyll pigments content (Figure 4C). Content of chl a was reduced gradually with increasing the rate of applied fermented brown juice. Application of fermented brown juice at low rates (i.e., $0.5 \%$ ) significantly improves the chl a content recording the highest value among all other treatments but was similar to control plants. On the other hand, the $c h l b$ content was found to respond negatively to increasing the rate of applied fermented brown juice as a gradual significant reduction was noticed. Content of total chl $a+b$ displayed a similar tendency as it slightly decreased with increasing the rate of fermented brown juice. The low rate of fermented brown juice showed a slightly higher content than the control, but this increase was not significant (Figure 4C). Except treatment of 0.5\% fermented brown juice, carotenoids content in all treatments including the control showed similar values as no significant differences were statistically measured. The lowest carotenoids content was determined in leaves of plants that received $0.5 \%$ fermented brown juice (Figure $4 \mathrm{C}$ ).
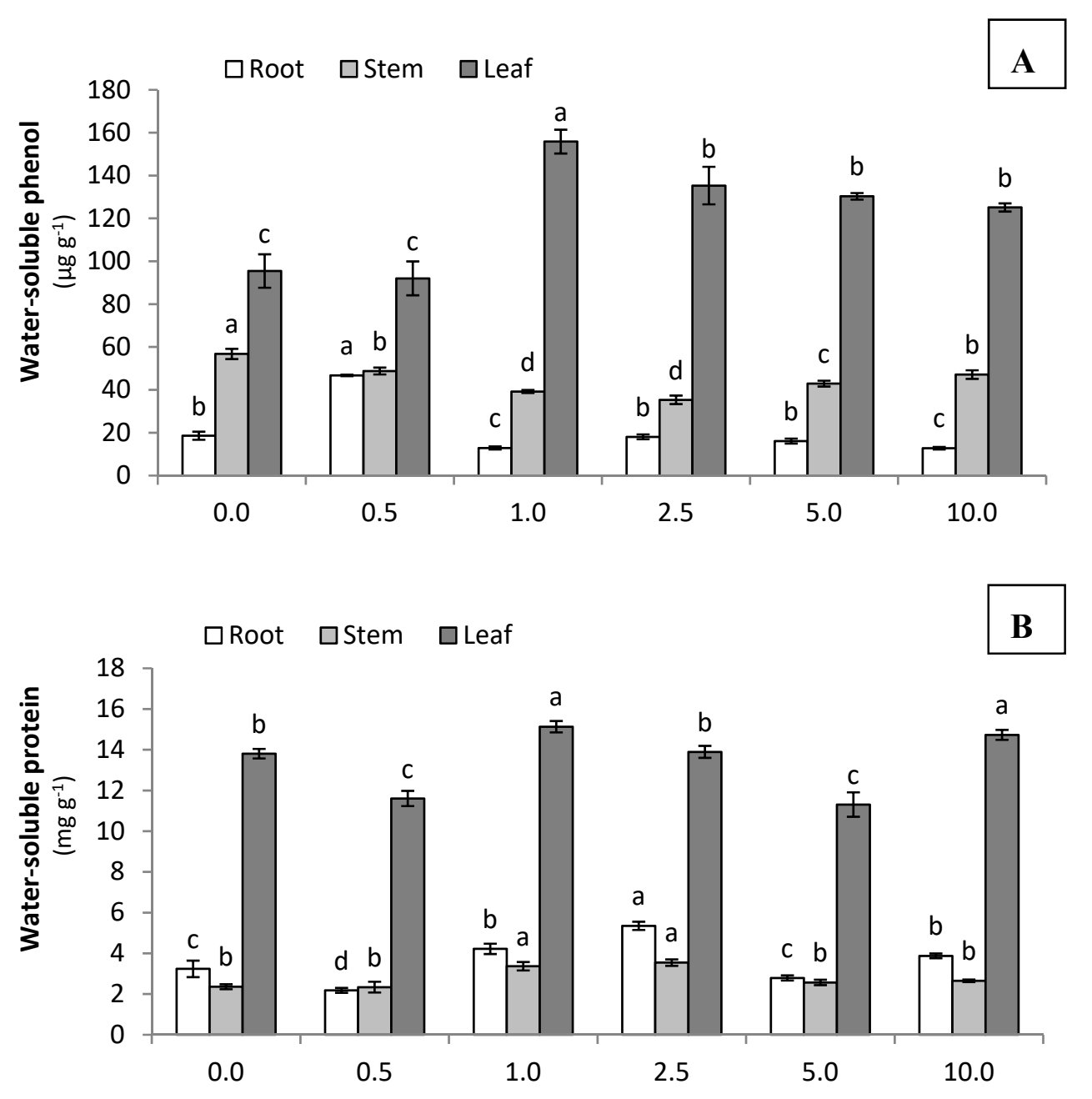

Figure 4. Cont. 


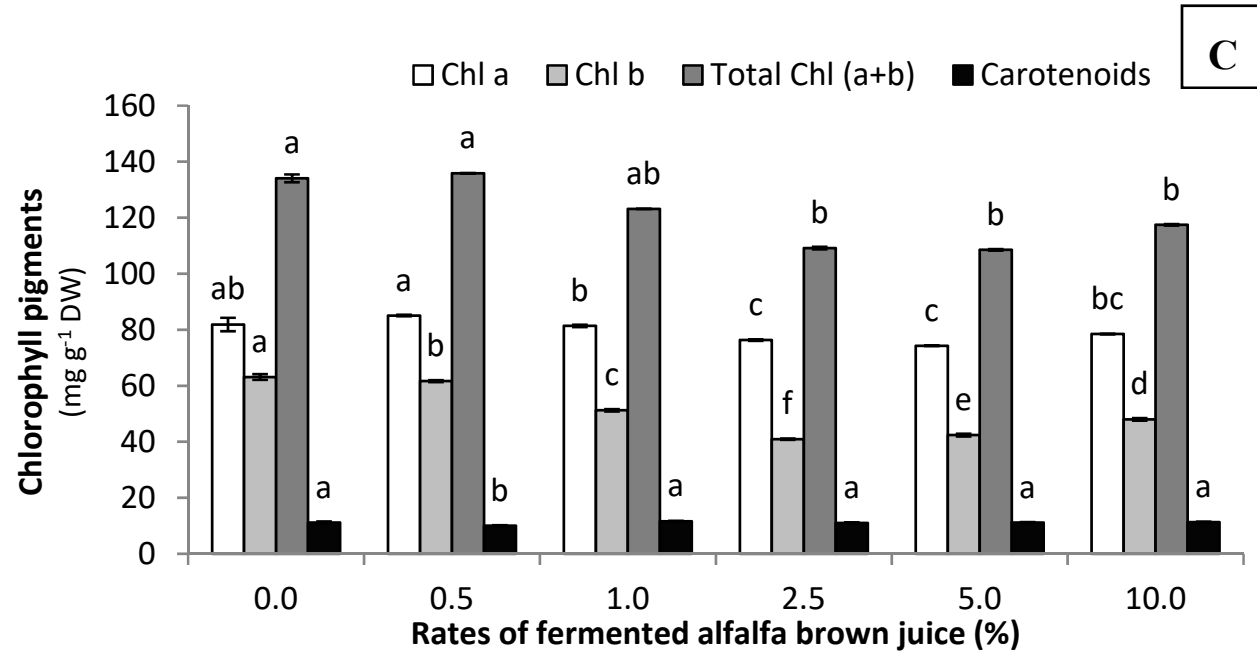

Figure 4. Water-soluble phenol (A), water-soluble protein (B), and chlorophyll pigments contents (C) in different plant tissues of Celosia plants sprayed at different rates of fermented alfalfa brown juice. Sample size $(n=6)$. Different letters above the same columns show significant differences at the level of $p<0.05$.

\subsubsection{Anatomical Features of Celosia Stem after Brown Juice Application}

Regarding the cross-sections, 10-15 cm from the apex were analyzed, and the tissue structure was representative of an older Celosia's stem anatomy, with successive cambia [39,40]. Stems were covered by the epidermis (single row); beneath its primer cortex containing angular collenchyma (four to six cells thick) was visible. In the pith primary vascular bundles were located surrounded by a cylinder of anomalous cambium. Secondary and primary vascular tissues were separated by the conjunctive tissue [41]. Both the conjunctive tissue and the inner part of the pith were composed of parenchymatous cells (Figure 5).

There is no fundamental difference in the tissue structure in connection with the treatment, but there are significant differences in the thickness of the tissues, which support the differences that are visible to the naked eye too (e.g., thicker, stiffer stem). All levels of concentration caused a reduction in the thickness of the epidermis, while it was the $1 \%$ treatment that caused a reduction to a greater extent. The thickness of the primary cortex reinforced with angular collenchyma was decreased by most treatments, except the $0.5 \%$ and $10 \%$ treatments, where statistically verified thickening was observed. The proportion of pith involved vascular tissues increased for all treatments. The more concentrated brown juice treatments resulted in significantly thicker primary vascular tissues, except the $1 \%$ and the $10 \%$ treatments. Growing of the secondary vascular tissue was the highest at the $0.5 \%$ treatment, where the new successive cambium formed almost entirely closed xylem and phloem, significantly contributing to the strength of the stem (Table 3).

Table 3. Impact of different concentrations of fermented brown juice on stem tissue of Celosia argentea var. plumosa $(\mu \mathrm{m})($ mean $\pm \mathrm{SD}, n=45)$.

\begin{tabular}{cccccc}
\hline & Epidermis & Cortex & Pith & Primary Vascular & \multicolumn{2}{c}{ Secondary Vascular } \\
Bundle & Tissue \\
\hline Cont. & $31.44 \pm 5.28 \mathrm{a}$ & $356.14 \pm 57.69 \mathrm{ab}$ & $1873.30 \pm 295.29 \mathrm{~b}$ & $236.47 \pm 79.43 \mathrm{~b}$ & $221.47 \pm 51.79 \mathrm{~b}$ \\
$0.5 \%$ & $30.81 \pm 6.72 \mathrm{a}$ & $374.10 \pm 99.50 \mathrm{ab}$ & $1903.79 \pm 187.39 \mathrm{~b}$ & $271.65 \pm 73.59 \mathrm{ab}$ & $295.59 \pm 76.55 \mathrm{a}$ \\
$1 \%$ & $25.83 \pm 3.59 \mathrm{~b}$ & $322.42 \pm 61.76 \mathrm{bc}$ & $2033.30 \pm 205.45 \mathrm{~b}$ & $242.23 \pm 41.22 \mathrm{~b}$ & $212.56 \pm 51.56 \mathrm{~b}$ \\
$2.5 \%$ & $28.50 \pm 4.42 \mathrm{ab}$ & $261.69 \pm 19.64 \mathrm{~d}$ & $2011.11 \pm 198.88 \mathrm{~b}$ & $303.98 \pm 88.94 \mathrm{a}$ & $230.18 \pm 73.69 \mathrm{~b}$ \\
$5 \%$ & $31.43 \pm 3.81 \mathrm{a}$ & $339.46 \pm 68.14 \mathrm{~b}$ & $2227.77 \pm 310.33 \mathrm{a}$ & $348.30 \pm 122.47 \mathrm{a}$ & $256.93 \pm 66.78 \mathrm{a}$ \\
$10 \%$ & $28.69 \pm 3.49 \mathrm{ab}$ & $392.07 \pm 91.05 \mathrm{a}$ & $1915.50 \pm 209.11 \mathrm{~b}$ & $310.12 \pm 102.47 \mathrm{a}$ & $274.80 \pm 89.62 \mathrm{a}$ \\
\hline
\end{tabular}

Notes: Different letters in each column indicate statistically significant differences $(p<0.05)$. 

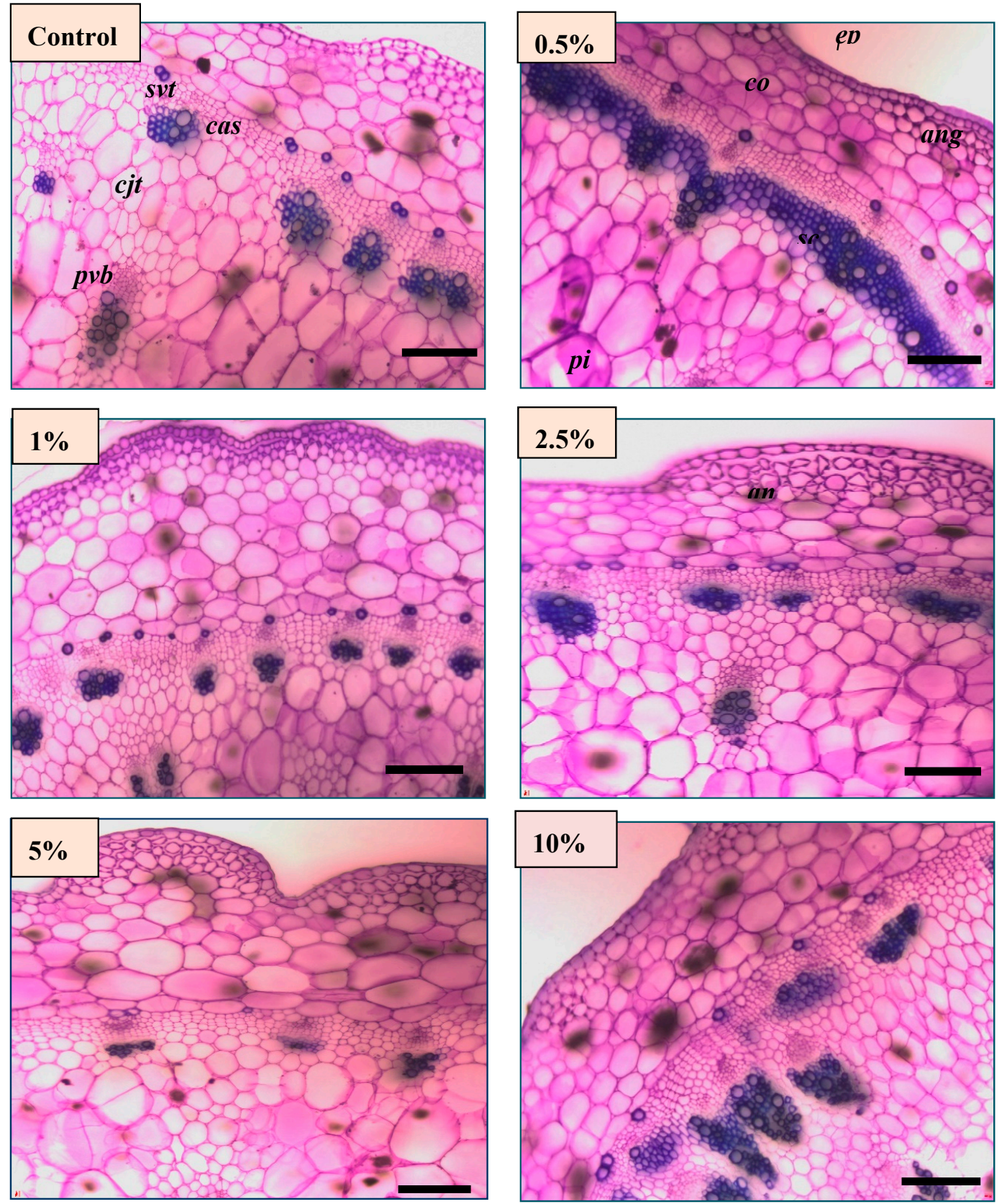

Figure 5. Anatomical sections of Celosia argentea var. plumosa stem. ep epidermis, co cortex, ang angular collenchyma, $p i$ pith, sc successive cylinder ( $s v t$ secondary vascular tissue), $c a$ cambium, $c j t$ conjunctive tissue, $\boldsymbol{p} \boldsymbol{v} \boldsymbol{b}$ primary vascular bundle after spraying Celosia plants with different rates of fermented brown juice (i.e., control, $0.5 \%, 1 \%, 2.5 \%, 5 \%$, and 10\%). Scale bar is $200 \mu \mathrm{m}$.

To sum up, it can be stated that the brown juice treatments (applied as foliar) influence the proportions of the Celosia stem's tissue. As a result of the treatments, the thinning of the epidermis and the intense growth of the vascular tissues (especially the secondary vascular tissue) can be projected. The growth rate of secondary tissues within the pith is the highest at $0.5 \%$ treatment.

\section{Discussion}

Recently, isolation of protein from plant green leaves has gained increasing attention as an attempt to bridge the gap between protein production and demand due to the dramatic increase in population and the increase in living standards. Brown juice (referred to as deproteinized plant juice or DPJ as 
well) is a byproduct generated during the coagulation of soluble protein in green juice through thermal treatment. Brown juice has gained less attention than LPC and press cake. It represents nearly $50 \%$ of pressed and pulped fresh biomass [9]. Therefore, these huge amounts could be an obstacle facing the acceleration of this approach and its acceptance by both politicians and the public. Disposal of alfalfa brown juice is a serious issue in LPC production due to its high biological oxygen demand (BOD) and carbohydrates content [42]. Due to its richness in free amino acids, peptides, soluble sugars, vitamins, and many macro- and microelements, it can be directed towards animal feeding and production of many chemicals [43]. Additionally, it can be used as a fertilizer, growth stimulator and/or growth medium for microorganisms [42]. Although some pieces of literature have been reporting the possible utilization of brown juice as a ruminant feed [44], few studies have been focusing on brown juice as a fertilizer [42,45].

During our recent experiments on LPC production from alfalfa biomass, it became clear that the storage of the brown juice at room conditions leads to fast spoiling. Therefore, we had to store it below $4{ }^{\circ} \mathrm{C}$. This may be due to its high carbohydrate content, which represents a suitable environment for bacteria to grow [42]. Therefore, converting sugars into organic acids and subsequent decrease in the $\mathrm{pH}$ of brown juice through fermentation using lactic acid bacteria seemed to be an ideal solution since fermented brown juice is stable and this facilitates its handling.

Lactic acid bacteria have long been known for their role in the fermentation of carbohydrates. Consequently, it has wide applications in medicine and food processing. Nowadays, lactic acid bacteria have been found to play an important role in agriculture, bioenergy production, and bioremediation of the environment [46]. In the present study we, firstly, aimed to stabilize alfalfa brown juice through reducing its water-soluble sugars content and $\mathrm{pH}$ using lactic acid bacteria. Accordingly, sugars content in brown juice was reduced after fermentation, because lactic acid bacteria use sugars as energy and carbon sources [47]. As shown in Table 1, most of the sugars in brown juice were found to be below the quantification limits after fermentation indicating that lactic acid bacteria consumed them. Comparable results have been previously presented by many researchers $[48,49]$. On the other hand, organic acids (e.g., lactic, acetic, and propionic acids) were increased in fermented brown juice causing a subsequent reduction in $\mathrm{pH}$ (Table 1). Novik, et al. [46] reported lactic acid as the main acid produced after fermentation of water-soluble sugars such as glucose and fructose either monomer or oligomer by lactic acid bacteria. Similar findings were cited by Bautista-Trujillo et al. [48], who observed a decrease in $\mathrm{pH}$ of maize silage after inoculation by lactic acid bacteria due to the increase in the production of organic acids, mainly lactic and acetic acids. Moreover, they reported an increase of $46.3 \%$ in lactic acid content. However, lactic acid content was found to increase by 8 -fold after fermentation compared to unfermented brown juice (Table 1). This high increase in lactic acid content may be attributed to the initial low $\mathrm{pH}$ of fresh brown juice (4.54), which helps to hydrolyze the oligo- and polysaccharides, therefore they become available for lactic acid bacteria [48]. Additionally, another possible reason for high lactic acid content could be attributed to the high Mn content in brown juice. Cheng et al. [49] stated that applying Mn to Jerusalem artichoke juice enhanced the lactic acid production by lactic acid bacteria up to $12 \mathrm{~g} \mathrm{~L}^{-1}$. Moreover, Dimitrovski et al. [50] stated that the fermentation of Jerusalem artichoke tuber juice by lactic acid bacteria reduced its $\mathrm{pH}$ from 6.5 to $4.7 \mathrm{after} 30 \mathrm{~h}$. In the current study, at the end of the fermentation process, the $\mathrm{pH}$ of brown juice was 3.91. Lactic acid bacteria significantly reduced the absorbance of brown juice by $35.9 \%$. This result was supported by that previously cited by Kwaw et al. [51]. They studied the effect of different strains of lactic acid bacteria on colorimetric properties of mulberry juice, reporting a $6.9 \%$ reduction in the color. They referred this reduction to the increase in content of the monomeric anthocyanin. Although an increase in total phenolic content has been previously reported for fermented mulberry juice [51] and pomegranate juice [52], our results displayed a decrease of $33.4 \%$ after inoculation of brown juice by lactic acid bacteria. Except $\mathrm{N}, \mathrm{P}, \mathrm{K}$, and $\mathrm{S}$ other macro- and microelements were higher in fermented alfalfa brown juice (Table 2). The reduction in concentrations of N, P, K, and S could be attributed to the fact that they are essential elements for the growth of lactic acid bacteria. However, similar findings were described 
by Kim [53], who stated that fermented kale juice had higher elemental composition than unfermented juice. Moreover, he cited significant differences between kale juice fermented by different lactic acid bacterial strains. The increase in the concentration of microelements, in particular, may be due to the increase of brown juice acidity. Although, the concentration of macronutrients (e.g., N, P, and K) was reduced after fermentation, the content of macro- and microelements is still high, and this makes the fermented brown juice a potential growth stimulator. On the whole, these results are supported by earlier findings of Ream et al. [45]. They reported that alfalfa brown juice contains a relatively high content of $\mathrm{N}$ and $\mathrm{K}$, in addition to small amounts of $\mathrm{P}, \mathrm{Ca}, \mathrm{Mg}$, and other microelements.

In the present study, fermented alfalfa brown juice as a growth stimulator was evaluated using the Celosia plant as a model. Brown juice was applied at different rates by foliar application. The foliar application of fermented brown juice showed a significant potential on the development of Celosia seedlings in comparison with control. Noticeably, increasing the application rate of brown juice sprayed on Celosia seedlings led to a considerable reduction in shoot parts, particularly the stem length. From a horticultural point of view, this seems to be a good result since the target is the flower not the vegetative growth of Celosia. Application of brown juice at low rates such as $0.5 \%$ and $1.0 \%$ enhanced the growth and resulted in high values of stem length, the volume of stem and root, fresh masses of stem and root, and number of leaves. Shorter but more branched root systems were observed when Celosia seedlings were sprayed with brown juice (Figure 2). This phenomenon is supported by data of length and the volume of roots (Figure 1). The beneficial effect of alfalfa brown juice could be attributed to its high content of macro- (i.e., $\mathrm{N}, \mathrm{P}, \mathrm{K}, \mathrm{Ca}$, and $\mathrm{Mg}$ ) and microelements (i.e., $\mathrm{S}, \mathrm{Mn}, \mathrm{Fe}, \mathrm{Cu}$, $\mathrm{Zn}$, and Mo); all in phyto-available forms (Table 2). Similarly, Ream et al. [45] observed that using brown juice as a fertilizer added at an annual rate of $1.25 \mathrm{~cm}$ induced the growth and yield of alfalfa, corn, and bromegrass; while, at the higher rate $(2.5 \mathrm{~cm})$ a reduction in yield and plant damage were noticed in all crops. However, they referred to the damage in plant growth caused by high rates of brown juice to unknown reasons; moreover, they considered it a not serious problem since the added amount of brown juice can be controlled. These results are supported by findings of Reddy et al. [42], who earlier stated that the application of alfalfa brown juice at low rates enhanced germination and growth of cowpea, mung bean, and groundnut; while high rates inhibited the germination and reduced the plant growth. They reported that alfalfa brown juice can be used as a fertilizer if it would be added at a lower level than $10 \%$. Additionally, they could not give a reason for such damaging effects of high rates of brown juice, except what previously was mentioned by Pirie [54], who stated that alfalfa brown juice contains some phytotoxic organic compounds.

In our experiment, the reduction in plant growth of treated Celosia plants at high rates of fermented brown juice can be explained by high $\mathrm{EC}$ value and low $\mathrm{pH}$ of brown juice solutions. Increasing the rates of brown juice caused a gradual increase in EC and a decrease in $\mathrm{pH}$ as shown in Table 4. At treatment of $0.5 \%$ brown juice, $\mathrm{EC}\left(\mathrm{dS} \mathrm{m}^{-1}\right)$ and $\mathrm{pH}$ were 0.12 and 4.21 , respectively; while, at the highest applied rate $10 \%$ they were 1.99 and 4.38 , respectively. Low $\mathrm{pH}$ is not favorable for the development of plants; it reduces photosynthesis due to a reduction in stomatal conductance [55]. This might explain why we found diminished growth of Celosia plants treated at high rates of brown juice. However, in the current study, the lowest $\mathrm{pH}$ was 4.38 when Celosia plants received $10 \%$ fermented brown juice. Long et al. [56] had earlier reported a reduction in citrus growth below $\mathrm{pH} 4$, while higher $\mathrm{pH}$ did not inhibit the growth and seedlings reached their maximum growth at $\mathrm{pH} 5$. The reduction in growth may be attributed to $\mathrm{H}^{+}$-toxicity which damages leaves. Absorption of nutrients applied as foliar application depends on the $\mathrm{pH}$ of the solution. Extreme $\mathrm{pH}$ (below 2 and above 12) was reported to burn the leaves. Moreover, some elements prefer different $\mathrm{pH}$ values for their optimum absorption by plant leaves.

Antioxidant enzymes such as CAT and POD are among the most important antioxidant enzymes which play a vital role in scavenging reactive oxygen species generated in cells due to different biotic and abiotic stresses [57]. Thus, enhancing the activity of these enzymes is considered an important step in improving the plants' tolerance to different kinds of stress [58,59]. The results abstracted from this 
research showed that the application of alfalfa brown juice after fermentation by lactic acid bacteria significantly increased the activity of CAT and POD in different Celosia tissues. However, the low rates of brown juice seemed to be more effective than higher ones, as a reduction in the activities was noticed. These results are confirmed by results of MDA, as treated plants with fermented brown juice had lower MDA content than control plants (untreated plants) regardless of the type of plant tissues. These results demonstrate that fermented brown juice can potentially be exploited as a growth stimulator, particularly at low rates. Besides, fermented brown juice had a significant effect on water-soluble phenol and protein contents, as they were higher in treated plants in comparison to control ones. The high rates of brown juice were found to reduce the photosynthetic pigment content. This could be attributed to low $\mathrm{pH}$ at high rates of fermented brown juice. This result was in accordance with that cited by Solati et al. [60], who reported a decrease in chlorophyll content due to low $\mathrm{pH}$.

Brown juice could be very useful as a soil fertilizer/conditioner particularly in alkaline soils and/or sandy soil due to its rich composition in macro- and microelements and sugars. These could induce the microbial growth in soil increasing soil fertility. Additionally, sugars play an important role in soil stabilization through maintaining soil aggregation, which subsequently leads to better water holding capacity $[42,61]$. While delivering deeper insights into the possible use of alfalfa brown juice as a growth stimulator and trying to precisely determine the most effective rate and application method, there are many issues that should be addressed in the future [62]. Results, undoubtedly, suggest that brown juice tolerance can be plant species dependent; therefore, more studies on different plant species at different rates of brown juice are crucially needed. Additionally, phytotoxicity of brown juice should be the focus of future studies.

Table 4. $\mathrm{pH}$ and electrical conductivity $\left(\mathrm{EC}, \mathrm{dS} \mathrm{m} \mathrm{m}^{-1}\right.$ ) values of alfalfa brown juice solutions before and after fermentation at the beginning of the experiment.

\begin{tabular}{ccccc}
\hline \multirow{2}{*}{$\begin{array}{c}\text { Rates of Brown } \\
\text { Juice (\%) }\end{array}$} & \multicolumn{2}{c}{$\mathbf{p H}$} & EC \\
\cline { 2 - 5 } & Before & After & $0.15 \pm 0.01$ & After \\
\hline $\mathbf{0 . 5}$ & $4.65 \pm 0.02^{+}$ & $4.21 \pm 0.07$ & $0.12 \pm 0.03$ \\
$\mathbf{1 . 0}$ & $4.67 \pm 0.02$ & $4.16 \pm 0.00$ & $0.67 \pm 0.07$ & $0.54 \pm 0.58$ \\
$\mathbf{2 . 5}$ & $4.68 \pm 0.01$ & $4.16 \pm 0.01$ & $1.20 \pm 0.04$ & $0.46 \pm 0.02$ \\
$\mathbf{5 . 0}$ & $4.72 \pm 0.01$ & $4.18 \pm 0.00$ & $2.26 \pm 0.04$ & $1.44 \pm 0.12$ \\
$\mathbf{1 0 . 0}$ & $4.72 \pm 0.01$ & $4.19 \pm 0.00$ & & \\
\hline
\end{tabular}

Notes: ${ }^{\dagger}$ Standard deviation.

\section{Conclusions}

The present study highlights the possible use of alfalfa brown juice as a growth stimulator. Brown juice is a serious problem in LPC production, where its disposal represents a threat to the environment due to its high content of water-soluble sugars as well as macro- and microelements. Fermentation of brown juice using lactic acid bacteria significantly improved its nutritional value and stability, because these bacteria—as our data showed-produce a significant amount of organic acids i.e., lactic, acetic, and propionic acids through their metabolism making the nutrients more available and the $\mathrm{pH}$ of row material (brown juice) lower, thereby stabilizing it. Most water-soluble sugars were under the detectable level after fermentation as the bacteria used them as carbon source. Moreover, the concentration of nutrients increased - showing the effect of bacteria for nutrient availability-after fermentation except N, P, K, and S showed a slight decrease. In this study, treating Celosia argentea, a valuable ornamental species with significant food and medical uses, with low rates of fermented brown juice through foliar application significantly improved the growth, as all of the vegetative parameters such as stem and root length, shoot and root volume, fresh mass of stem and root, and the number of leaves increased. The brown juice treatments in low $(0.5 \%)$ concentration caused positive changes in histological parameters, in the growth rate of secondary tissues. Additionally, fermented 
brown juice showed a considerable impact on the antioxidant capacity of Celosia plants, as CAT and POD activities increased while MDA content decreased. Moreover, both water-soluble phenol and protein were found to increase in treated plants with fermented brown juice compared to the control showing the beneficial effect of lactic acid fermentation and chemical properties of brown juice. These results conclude and state the potential use of fermented alfalfa brown juice as a sustainable growth stimulator for crops with a particular interest in horticultural crops. Our data regarding the chemical and microbiological properties of brown juice and the effects (listed plant responses) it triggered confirm the scientific investigations where plant growth-promoting properties of lactic acid bacteria contribute greatly to the maintenance of the health of plants (also strengthening disease resistance) and by consuming these plants, they are also beneficial in human digestive processes. It should be noted that the sample size number was modest in our study that is why it was difficult to draw strong far-going conclusions, however preliminary conclusions support the fact that phytomicrobiome engineering can be a promising strategy for sustainable agriculture, but the data available is limited to understand properly these complex symbiotic relationships. Therefore, examination of fermented alfalfa brown juice's effect on physiological, biochemical, and anatomical parameters of other horticultural and agricultural crops is in progress.

Author Contributions: Conceptualization, N.B., S.K. and M.G.F.; methodology, D.B., N.E. and I.O.T.; software, D.B.; validation, D.B. and I.O.T.; formal analysis, N.A. and S.K.; investigation, M.R. and C.F.; resources, H.E.-R. data curation, T.A.; writing-original draft preparation, N.B. and D.B.; writing—review and editing, N.B., T.A., H.E.-R. and D.B.; visualization, S.K.; supervision, M.G.F.; project administration, N.B.; funding acquisition, N.B. All authors have read and agreed to the published version of the manuscript.

Funding: This research received no external funding.

Acknowledgments: The research was financed by the Higher Education Institutional Excellence Programme (NKFIH-1150-6/2019) of the Ministry of Innovation and Technology in Hungary, within the framework of the Biotechnology thematic programme of the University of Debrecen."; "Complex Rural Economic and Sustainable Development, Elaboration of its Service Networks in the Carpathian Basin (Project ID: EFOP-3.6.2-16-2017-00001, Hungary)" research project. Also, support was given by Tempus Public Foundation (TPF), Hungary and Széchenyi 2020 under the GINOP-2.2.1-15-2017-00051.

Conflicts of Interest: The authors declare no conflict of interest.

\section{References}

1. Tripathi, A.D.; Mishra, R.; Maurya, K.K.; Singh, R.B.; Wilson, D.W. Estimates for world population and global food availability for global health. In The Role of Functional Food Security in Global Health; Academic Press: Cambridge, MA, USA.

2. Alexandratos, N.; Bruinsma, J. World Agriculture towards 2030/2050: The 2012 Revision; ESA Working Paper No. 12-03; FAO: Rome, Italy, 2012.

3. Henchion, M.; Hayes, M.; Mullen, A.M.; Fenelon, M.; Tiwari, B. Future Protein Supply and Demand: Strategies and Factors Influencing a Sustainable Equilibrium. Foods 2017, 6, 53. [CrossRef] [PubMed]

4. Boer, J.; Aiking, H. Strategies towards healthy and sustainable protein consumption: A transition framework at the levels of diets, dishes, and dish ingredients. Food Qual. Prefer. 2019, 73, 171-181. [CrossRef]

5. Tenorio, A.T.; Kyriakopoulou, K.E.; Suarez-Garcia, E.; van den Berg, C.; van der Goot, A.J. Understanding differences in protein fractionation from conventional crops, and herbaceous and aquatic biomass-Consequences for industrial use. Trends Food Sci. Technol. 2018, 71, 235-245. [CrossRef]

6. Kromus, S.; Wachter, B.; Koschuh, W.; Mandl, M.; Krotscheck, C.; Narodoslawsky, M. The green biorefinery Austria-development of an integrated system for green biomass utilization. Chem. Biochem. Eng. Q. 2004, 18, $7-12$.

7. Zhang, W.; Grimi, N.; Jaffrin, M.Y.; Ding, L.; Tang, B. A short review on the research progress in alfalfa leaf protein separation technology. J. Chem. Technol. Biotechnol. 2017, 2, 2894-2900.

8. Tenorio, A.T.; Gieteling, J.; de Jong, G.A.H.; Boom, R.M.; van der Goot, A.J. Recovery of protein from green leaves: Overview of crucial steps for utilisation. Food Chem. 2016, 203, 402-408. [CrossRef]

9. Manwatkar, V.G.; Gogle, D.P. The Effect of Deproteinised Juice (DPJ) on Seed Germination and Seedling Growth of Different Plants (by Paper Towel Method). Int. J. Life Sci. 2014, 2, 65-68. 
10. Cheyniera, V.; Comte, G.; Davies, K.M.; Lattanzio, V.; Martens, S. Plant phenolics: Recent advances on their biosynthesis, genetics, and ecophysiology. Plant. Physiol. Biochem. 2013, 72, 1-20. [CrossRef]

11. Salah, E.H. Sustainability of Agricultural and Rural Waste Management, 1st ed.; Cradle-to-Cradle for Sustainable Development eBook; Academic Press: New York, NY, USA, 2007; 424p, ISBN 9780080550145.

12. Popp, J.; Lakner, Z.; Harangi-Rakos, M.; Fari, M. The effect of bioenergy expansion: Food, energy, and environment. Renew. Sustain. Energy Rev. 2014, 32, 559-578. [CrossRef]

13. Obi, F.O.; Ugwuishiwu, B.O.; Nwakaire, J.N. Agricultural waste concept, generation, utilization and management. Niger. J. Technol. 2016, 35, 957-964. [CrossRef]

14. Grela, E.R.; Pietrzak, K. Production technology, chemical composition and use of alfalfa protein-xanthophyll concentrate as dietary supplement. J. Food Process. Technol. 2014, 5, 10.

15. Pirie, N.W. Leaf Protein and its By-products in Human and Animal Nutrition; Cambridge University Press: Cambridge, UK, 1987; p. 209.

16. Iliyas, S. Effect of different flours on $\alpha$-amylase production. Int. J. Bioassays 2014, 3, 3011-3015.

17. Jadhav, R.K.; Chhaya, G. Influence of deproteinised foliage fluid liquid biofertilizer on nitrate reductase activity of Eleusine coracana plants. Curr. Bot. 2018, 9, 33-36. [CrossRef]

18. Zanin, V. A New Nutritional Idea for Man: Lucerne Leaf Concentrate. APEF, Association Pour la Promotion des Extraits Foliaires en Nutrition. 1998. Available online: http://www.nutrition-luzerne.org/anglais/pdf/ EtudeZaninenglish.pdf (accessed on 29 October 2019).

19. Thomsen, M.H.; Bech, D.; Kiel, P. Manufacturing of Stabilised Brown Juice for L-lysine production-From University Lab Scale over Pilot Scale to Industrial Production. Chem. Biochem. Eng. Q. 2003, 18, 37-46.

20. Shende, G.C.; Gogle, D.P. To study the effect of various concentration of deproteinized leaf juice (DPJ) of selected plants on growth of Aspergillus niger. Int. J. Life Sci. 2016, 6, 186-188.

21. Jadhav, R.K.; Kadam, R.; Joshi, D. Physiology of Gramineae Crops by Deproteinised Foliage Extract and its Influence on Photosynthetic Chemistry. J. Phytochem. 2019, 110, 149-163.

22. Hegyi, F. Examination of Lactobacilli by Advanced Colorimetric Method. In Hungarian. Laktobacilluszok Vizsgálata továbbfejlesztett Kolorimetriás Módszerrel. Ph.D. Thesis, Corvinus University, Budapest, Hungary, 2014; pp. 8-93.

23. Lamont, J.R.; Wilkins, O.; Bywater-Ekegard, M.; Smith, D.L. From yogurt to yield: Potential applications of lactic acid bacteria in plant production. Soil Biol. Biochem. 2017, 111, 1-9. [CrossRef]

24. Smith, D.L.; Subramanian, S.; Lamont, J.R.; Bywater-Ekeg€ard, M. Signaling in the phytomicrobiome: Breadth and potential. Front. Plant Sci. 2015, 6, 709. [CrossRef]

25. Smith, D.L.; Praslickova, D.; Ilangumaran, G. Inter-organismal signaling and management of the phytomicrobiome. Front. Plant. Sci. 2015, 6, 722. [CrossRef]

26. Tang, Y.; Xin, H.-L.; Guo, M.-L. Review on research of the phytochemistry and pharmacological activities of Celosia argentea. Rev. Bras. Farmacogn. 2016, 26, 787-796. [CrossRef]

27. Gupta, S.; Lakshmi, A.J.; Manjunath, M.N.; Prakash, J. Analysis of nutrient and antinutrient content of underutilized green leafy vegetables. LWT Food Sci. Technol. 2005, 38, 339-345. [CrossRef]

28. Fári, M.G.; Domokos-Szabolcsy, É. Method for Producing Plant Protein Coagulum. Hun Patent WO/2019/150144, 8 August 2019.

29. Gibbs, P.A. Novel uses for lactic acid fermentation in food preservation. J. Appl. Bacteriol. 1987, 63, 51S-58S. [CrossRef]

30. Kovács, B.; Győri, Z.; Prokisch, J.; Loch, J.; Dániel, P. A study of plant sample preparation and inductively coupled plasma emission spectrometry parameters. Commun. Soil Sci. Plant Anal. 1996, 27, 1177-1198. [CrossRef]

31. Boór, A.; Bélafiné Bakó, K. Determination of antioxidant content in sloe (Prunus spinosa L.) and dogwood (Cornus mas L.) fruits. In Proceedings of the Conference of Chemical Engineering '2010, Singapore, 26-28 February 2010; pp. 55-58. (in Hungarian).

32. Sparks, D.L.; Page, A.L.; Helmke, P.A.; Loppert, R.H.; Soltanpour, P.N.; Tabatabai, M.A.; Johnston, C.T.; Summner, M.E. Methods of Soil Analysis: Chemical Methods; Part 3; ASA and SSSA: Madison, WI, USA, 1996.

33. Bradford, M. A rapid and sensitive method for the quantitation of microgram quantities of protein utilizing the principle of protein-dye binding. Anal. Biochem. 1979, 72, 248-254. [CrossRef] 
34. Roxas, V.P.; Smith, R.K.; Allen, E.R.; Allen, R.D. Overexpression of glutathione S-transferase/glutathione peroxidase enhances the growth of transgenic tobacco seedlings during stress. Nat. Biotechnol. 1997, 15, 988-991. [CrossRef] [PubMed]

35. Woodbury, W.; Spencer, A.K.; Stahmann, M.A. An improved procedure using ferricyanide for detecting catalase isozymes. Anal. Biochem. 1971, 44, 301-305. [CrossRef]

36. Zhang, Z.; Huang, R. Analysis of Malondialdehyde, Chlorophyll Proline, Soluble Sugar, and Glutathione Content in Arabidopsis seedling. Bio-Protocol 2013, 3, 1-8. [CrossRef]

37. Porra, R.J.; Thompson, W.A.; Kriedemann, P.E. Determination of accurate extinction coefficients and simultaneous equations for assaying chlorophylls a and $b$ extracted with four different solvents: Verification of the concentration of chlorophyll standards by atomic absorption spectroscopy. Biochim. Biophys. Acta 1989, 975, 384-394. [CrossRef]

38. Duncan, D.B. Multiple range and multiple F-tests. Biometric 1955, 11, 1-42. [CrossRef]

39. Balfour, E. Anomalous secondary thickening in Chenopodiaceae, Nyctaginaceae and Amaranthaceae. Phytomorphology 1965, 15, 111-122.

40. Myśkow, E.; Gola, E.; Tulik, M. Continuity of procambium and anomalous cambium during formation of successive cambia in Celosia argentea. J. Plant. Growth Regul. 2019, 38, 1458-1466. [CrossRef]

41. Carlquist, S. Successive cambia revisited: Ontogeny, histology, diversity, and functional significance. J. Torrey Bot. Soc. 2007, 134, 301-332. [CrossRef]

42. Reddy, G.U.; Deshmukh, V.R.; Joshi, R.N.; Kayama, R. Utilization of alfalfa (Mediacago sativa L.) whey as a fertilizer in irrigation. J. Jpn. Grassl. Sci. 1987, 33, 32-37.

43. Monteros, J.M.; Bouton, H.J. The future of alfalfa and forage crops. In Proceedings of the Western Alfalfa \& Forage Conference, Reno, Nevada, 2-4 December 2009.

44. Martin, N.P. Alfalfa: Forage crop of the future. In Proceedings of the 28th Kentucky Alfalfa Conference; Lacefield, G., Forsythe, C., Eds.; CaveCity Convention Center: Cave, KY, USA, 2008; pp. 17-26.

45. Ream, H.W.; Smith, D.; Walgenbach, R. Effects of deproteinized alfalfa juice applied to alfalfa-bromegrass, bromegrass, and corn. Agron. J. 1977, 69, 685-689. [CrossRef]

46. Novik, G.; Olga Meerovskaya, O.; Savich, V. Waste Degradation and Utilization by Lactic Acid Bacteria: Use of Lactic Acid Bacteria in Production of Food Additives, Bioenergy and Biogas. In Food Additives; Karunaratne, D.N., Pamunuwa, G., Eds.; IntechOpen: Rijeka, Croatia, 2017. [CrossRef]

47. Zubaidah, E.; Akhadiana, W. Comparative study of inulin extracts from dahlia, yam, and gembili tubers as prebiotic. Food Nutr. Sci. 2013, 4, 8-12. [CrossRef]

48. Bautista-Trujillo, G.U.; Cobos, M.A.; Ventura-Canseco, L.M.C.; Ayora-Talavera, T.; Abud-Archila, M.; Oliva-Llaven, M.A.; Dendooven, L.; Gutierrez-Miceli, F.A. Effect of Sugarcane Molasses and Whey on Silage Quality of Maize. Asian J. Crop Sci. 2009, 1, 34-39.

49. Cheng, X.; Dong, Y.; Su, P.; Xiao, X. Improvement of the fermentative activity of lactic acid bacteria starter culture by the addition of Mn. Appl. Biochem. Biotechnol. 2014, 174, 1752-1760. [CrossRef]

50. Dimitrovski, D.; Velickova, E.; Dimitrovska, M.; Langerholc, T.; Winkelhausen, E. Synbiotic functional drink from Jerusalem artichoke juice fermented by probiotic Lactobacillus plantarum PCS26. J. Food Sci. Technol. 2016, 53, 766-774. [CrossRef]

51. Kwaw, E.; Ma, Y.; Tchabo, W.; Apaliya, M.T.; Wu, M.; Sackey, A.S.; Xiao, L.; Tahir, H.E. Effect of lactobacillus strains on phenolic profile, color attributes and antioxidant activities of lactic-acid fermented mulberry juice. Food Chem. 2018, 1, 148-154. [CrossRef]

52. Valero-Cases, E.; Nuncio-Jáuregui, N.; Frutos, M.J. Influence of fermentation with different lactic acid bacteria and in vitro digestion on the biotransformation of phenolic compounds in fermented pomegranate Juices. J. Agric. Food Chem. 2017, 65, 6488-6496. [CrossRef]

53. Kim, S.Y. Production of fermented kale juices with Lactobacillus strains and nutritional composition. Prev. Nutr. Food Sci. 2017, 22, 231-236. [PubMed]

54. Pirie, N.W. Leaf Protein and Other Aspects of Fodder Fractionation; Cambridge University Press: London, UK, 1978; pp. 118-123.

55. Anugoolprasert, O.; Kinoshita, S.; Naito, H.; Shimizu, M.; Ehara, H. Effect of low pH on the growth, physiological characteristics and nutrient absorption of sago palm in a hydroponic system. Plant Prod. Sci. 2012, 15, 125-131. [CrossRef] 
56. Long, A.; Zhang, J.; Yang, L.T.; Ye, X.; Lai, N.W.; Tan, L.L.; Lin, D.; Chen, L.S. Effects of low pH on photosynthesis, related physiological parameters, and nutrient profiles of citrus. Front. Plant Sci. 2017, 8, 185. [CrossRef] [PubMed]

57. Anjum, N.A. Book review: Oxidative damage to plants-antioxidant networks and signaling. Front. Plant. Sci. 2015, 6, 452. [CrossRef]

58. Szollosi, R. Superoxide dismutase (SOD) and abiotic stress tolerance in plants: An overview. In Oxidative Damage to Plants; Academic Press: New York, NY, USA, 2014; pp. 89-129.

59. Santamaría-Fernández, M.; Karkov Ytting, N.; Lübeck, M. Influence of the development stage of perennial forage crops for the recovery yields of extractable proteins using lactic acid fermentation. J. Clean. Prod. 2019, 218, 1055-1064. [CrossRef]

60. Solati, Z.; Jørgensen, U.; Eriksen, J.; Søegaard, K. Dry matter yield, chemical composition and estimated extractable protein of legume and grass species during the spring growth. J. Sci. Food Agric. 2017, 97, 3958-3966. [CrossRef] [PubMed]

61. Kovács, Z.; Fári, M.G.; Kaszás, L.; Koroknai, J.Á.; Domokosné-Szabolcsy, É. Obtention of functional leaf protein concentrate (F-LPC) based on Ereky-process: Historical survey and preliminary results. New Biotechnol. 2018, 44, s100-s101. [CrossRef]

62. Kamm, B.; Hille, C.; Schönicke, P. Green biorefinery demonstration plant in Havelland (Germany). Biofuels Bioprod. Biorefin. 2010, 6, 253-262. [CrossRef]

(C) 2020 by the authors. Licensee MDPI, Basel, Switzerland. This article is an open access article distributed under the terms and conditions of the Creative Commons Attribution (CC BY) license (http://creativecommons.org/licenses/by/4.0/). 